DOI: 10.17707/AgricultForest.62.2.18

Eifediyi, E. K., H. E. Ahamefule, I. F. Ojiekpon, T.M. Agbede, S. U. Remison, T. H. Aliyu, T.O. Olukayode, and A. K. Bangura ${ }^{1}$

\title{
RESPONSE OF SESAME (Sesamum indicum L.) TO MULCHING AND INORGANIC FERTILIZER APPLICATION IN A SOUTHERN GUINEA SAVANNAH ZONE OF NIGERIA
}

\begin{abstract}
SUMMARY
Sesame is best cultivated towards the end of the wet season in the southern guinea savannah zone of Nigeria because when planted early in the season, high moisture regime will predispose the crop to increased vegetative growth at the expense of seed formation, discoloured grains and create an unfavourable environment for harvesting, drying and processing of the seeds. However, growing sesame towards the end of the rainy season may subject it to moisture stress especially with the uncertainty introduced by climate change. This therefore necessitated an investigation into the potentials of incorporating mulch practice to conserve moisture and fertilizer nutrients in sesame production. A field study was conducted in the Teaching and Research Farm of the University of Ilorin, Ilorin- Nigeria during the 2013 and 2014 cropping seasons to evaluate the effects of mulching and NPK fertilizer on the performance of sesame (ExSudan variety). Treatments consisted of three mulch types (no mulch (NM), grass mulch (GM) and wood shavings (WS) mulch applied at the rate of $0.5 \mathrm{t} \mathrm{ha}^{-1}$ ) and five levels of NPK fertilizer 20:10:10. The experiment was laid out in a $3 \times 5$ factorial arrangement replicated thrice. Data were collected on soil parameters (some physical and chemical properties), plant growth parameters (plant height, number of leaves and number of branches) and yield parameters (number of capsules per plant, weight of seeds per plant and weight of seeds per hectare). The result of the study indicated that using mulch alone increased the water holding capacity and the organic matter content of the soil. However, using the grass mulch and fertilizer at the rate of $300 \mathrm{kgha}^{-1}$ resulted in an increase in the growth and yield parameters which were significantly different $(\mathrm{P}<0.05)$ from the other treatments in both years. The average yield of the two years of study
\end{abstract}

\footnotetext{
${ }^{1}$ Eifediyi E. K, Department of Agronomy, University of Ilorin, Ilorin, NIGERIA (corresponding author: kevineifediyi@ yahoo.ca), H. E. Ahamefule, University of Ilorin, Ilorin, NIGERIA, A. K. Bangura, Department of Agronomy, University of Ilorin, Ilorin, NIGERIA, I. F. Ojiekpon, Agronomy Division, Rubber Research Institute of Nigeria, Iyanomo Benin City, NIGERIA, T.M. Agbede, Department of Agricultural Technology, Rufus Giwa Polytechnic, Owo, Ondo State, NIGERIA, S. U. Remison, Department of Crop Science, Ambrose Alli University, Ekpoma NIGERIA, T. H. Aliyu, Department of Crop Protection, University of Ilorin, Ilorin, NIGERIA, T.O. Olukayode, Division of Plant Pathology and Crop Protection, Goettingen University, Goettingen, GERMANY.

Notes: The authors declare that they have no conflicts of interest. Authorship Form signed online.
} 
indicated an overall seventy-one percent increase in seed weight per hectare in the grass mulched plots over the control.

Keywords: sesame, inorganic fertilizer, mulching, water holding capacity, yield

\section{INTRODUCTION}

Sesame or beniseed (Sesamum indicum L.) is from the Pedaliaceae family is an important oil seed crop which is cultivated in tropical and sub-tropical countries of Asia and Africa for its oil seed. According to Tunde-Akintunde and Akintunde (2007), its oil content is comparable to that of olive tree seed (Olea europaea). Young leaves are used as soup ingredients in sub-Saharan Africa. In India and China, the leaves play a role in the treatment of cancer while the seed cake left after oil extraction is an excellent livestock feed, which can also be used as manure, carrier for medicine and perfumes (Vossen and Mkamilo, 2007). It is cultivated in the savannah zones of Nigeria (Alegbejo, 2003) in smallholdings without the use of external inputs, which has adversely affected its yield potentials. The average yield in farmers` field is about $300 \mathrm{kgha}^{-1}$ which is grossly lower than yields elsewhere (Abubakar et al., 1998). The reason for this low yield can be attributed to poor cultural practices (Haruna and Usman 2005).

Usually, sesame is cultivated late in the season in the southern guinea savannah zone of Nigeria during which time there is torrential rainfall, which results in leaching of nutrients accompanied by high temperature that often leads to increased evaporation rate with subsequent low soil moisture content, which invariably affects dissolution of fertilizer. One way of overcoming this problem is by the use of mulch, which is a soil conservation practice that has been used for a long time to increase the organic matter and moisture contents of the soil, reduce soil temperature and prevent leaching of nutrients (Wien et al., 1993; Ahamefule and Peter, 2014). Khurshid (2006) stated that mulching has been reported to increase soil moisture content and stability of the topsoil while Anikwe et al.(2007) also reported that mulching provides a better soil environment, moderate soil temperature, increase soil porosity and infiltration and Tian (1994) asserted, that mulch materials perform additional function of increasing soil organic matter content, cation exchange capacity (CEC), biological activity, improves soil structure, increases plant nutrients after decomposition and subsequently enhancing plant growth and yield.

The use of mulch will conserve the moisture content in the soil taking into cognizance the time of planting of the crop thereby allowing the full utilization of available moisture and fertilizer nutrients at the root zone of the crop. Mbagwu (1990) reported higher nitrogen use efficiency for maize in mulched soils compared to non-mulched soils while Ahamefule and Peter (2014) similarly reported higher phosphorus use efficiency for cowpea plants. Apart from increasing soil fertility, mulch also serves as soil amendment by adding organic matter to the soil and suppress weed growth (Aguyoh et al.,1999). Grass mulch has been found to increase the nutrient content of soil following decomposition 
and mineralization; hence can increase the vegetative growth of plants, which ultimately results in high yield (Singh et al., 2007; Ahamefule and Peter, 2014) attributable to the reduction in soil temperature and improved moisture holding capacity of the soil (Lal, 1974).

Mineral fertilizer on the other hand, has been used to improve the yield of crops for many years especially in the southern guinea savannah zone of Nigeria, where it is a sine - qua-non in fertility management because of the inherently low organic matter content of the soils in the region. The fertility status has been further depleted as a result of constant bush fire and the reduction in the fallow periods due to increased population and infrastructural development. Benett and Wood (1995) had earlier reported that fertilizer rate depends on soil fertility, soil type and the previous crop. Rao et al. (1994) reported increase in sesame yield from the application of nitrogen fertilizer and Schilling and Cattan (1991) reported similar increase in sesame yields from the application of fertilizer containing nitrogen, phosphorus and sulphur.

Complementary use of NPK fertilizer and mulch will prove a sound fertility management practice in soils of the southern guinea savannah zone of Nigeria, because the nutrients $\mathrm{N}, \mathrm{P}$ and $\mathrm{K}$, are among the most limiting in the zone. This practice will enhance increased crop productivity as mulch will reduce the rate of leaching of fertilizer nutrients and significantly increase the available phosphorus and potassium contents in the soil (Cadavid et al., 1998). Liasu and Achakzai (2007) had reported that combination of mulch and inorganic fertilizer improved the growth and yield attributes of tomatoes.

Although, sesame can be cultivated in semi-arid regions because of its tolerance to drought, nevertheless in a world confronted with global warming and hence unpredictable rainfall, using mulch and fertilizer may bridge the yield differential between the guinea savannah zone of Nigeria and other sesame growing areas of the world. The objective of this study was therefore to evaluate the effects of mulching and NPK fertilizer on the growth and yield of sesame.

\section{The Experimental Site}

\section{MATERIAL AND METHODS}

The experiment was carried out during the wet seasons of 2013 and 2014 at the Teaching and Research Farm of the University of Ilorin, Ilorin $\left(9^{\circ} 29^{\prime} \mathrm{N}, 4^{\circ}\right.$ $35^{\prime} \mathrm{E}$ and $307 \mathrm{~m}$ above sea level) in a southern guinea savannah zone of Nigeria. The area is characterized by a mean annual rainfall of $1186 \mathrm{~mm}$, mean annual temperature of $29^{\circ} \mathrm{C}$ while the average annual relative humidity is about $85 \%$. The site was a two-year fallow land, which had previously been cropped, to maize and cassava prior to the establishment of the experiment.

\section{Field layout}

The land was ploughed and harrowed and raised seedbeds were made before marking out into plots. The size of each plot was $2 \mathrm{~m} \times 5 \mathrm{~m}$ with a $0.50 \mathrm{~m}$ avenue between the plots. Sowing was done by drilling the sesame seeds in shallow furrows and then covered lightly with soil. This was done in 2013 and 
2014.The plants were thinned down to two plants per stand at a spacing of $90 \times$ $30 \mathrm{~cm}$ between and within rows. Fertilizer (NPK 20:10:10) was applied three weeks after planting and weed control was done manually.

Soil samples collected from $0-30 \mathrm{~cm}$ depth (fifteen locations) prior to planting within the experimental plots were bulked and a sub-sample was taken for physical and chemical characterization.

\section{Experimental Design}

The experiment was laid out in a $3 \times 5$ factorial arrangement in randomized complete block design (RCBD). The factors were mulching (no mulching (NM), mulching with grass (GM) and mulching with wood shavings (WS)) and NPK fertilizer. These gave 15 treatment combinations which were replicated thrice.

Grass mulch from a nearby lawn containing pure stand of grasses and wood shavings from a nearby sawmill were collected and applied $(0.5 \mathrm{t} / \mathrm{ha})$ as mulch yearly.

\section{Data Collection}

Data were collected on vegetative (plant height, number of leaves, number of branches) and yield traits number of capsules, seed weight per plant).

\section{Vegetative Traits}

The plant height was assessed by measuring from the soil level to the crown of the plant in five randomly selected tagged plants using a measuring tape at 4, 6 and 8 weeks after planting. The number of leaves was assessed by visual count of the green leaves from the five-tagged plants at 4, 6 and 8 weeks after planting and the number of branches was assessed by visual count of the number of primary and secondary branches at 4, 6 and 8 weeks after planting.

\section{Yield and Yield components}

The number of capsules per pant was assessed by visual count of the number of capsules, the seed weight per plant was assessed by taking the weight of the five-tagged plants after drying and threshing using a sensitive balance. The seeds of the five-tagged plants were weighed and recorded and extrapolated to get the yield per hectare $\left(\mathrm{kg} \mathrm{ha}^{-1}\right)$. The combined yields for the two years were summed up and the mean recorded for the calculation of the two years yield.

\section{Laboratory analysis}

Soil pH was measured (soil: water ratio, 1:2) using a glass electrode; total $\mathrm{N}$ content was determined by micro - Kjeldahl method (Bremner, 1965); available phosphorus was determined following Bray No $1(1 \mathrm{~N} \mathrm{NH} 4 \mathrm{~F}+0.5 \mathrm{~N})$ $\mathrm{HCl}$ extractant by vanadomolybdophosphoric acid method (Kuo, 1996), organic carbon was determined by using the modified Walkley-Black method (Nelson 
and Sommers, 1996) and extraction of exchangeable bases was done by using $1 \mathrm{~N}$ ammonium acetate, exchangeable $\mathrm{K}$ and $\mathrm{Na}$ were determined using flame photometry while calcium and magnesium were analyzed by atomic absorption spectrophotometry. Total porosity was determined according to Ahamefule et al. (2014) and soil moisture contents at a depth of $15 \mathrm{~cm}$ was calculated as weight of wet soil (g) - weight of dried soil/ weight of dried soil multiplied by 100 using standard procedure.

\section{Data analysis}

Data collected were subjected to analysis of variance (ANOVA) using Genstat software package 12th Edition and where significant treatment effects were detected, the least significant difference (LSD) was used to compare means at $5 \%$ level of probability.

\section{RESULTS AND DISCUSSION \\ Soil Physico-chemical Properties}

Pre and post treatment soil investigations indicated that the soil had a moderately acidic reaction, the organic matter content was very low to moderately low, the nitrogen content was very low to moderately low, the phosphorus, potassium, calcium, and magnesium contents were low to moderately low (Table 1).

Table 1. Soil properties of the experimental site before and after cropping in 2013 and 2014.

\begin{tabular}{|c|c|c|c|c|c|c|c|c|}
\hline \multirow[t]{2}{*}{ Year } & \multirow[t]{2}{*}{$\begin{array}{c}\text { Soil } \\
\text { pH }\end{array}$} & Org C & $\begin{array}{l}\text { Org. } \\
\text { Matter }\end{array}$ & $\begin{array}{c}\text { Total } \\
\mathrm{N}\end{array}$ & \multirow{2}{*}{$\begin{array}{c}\mathrm{P} \\
\mathrm{Ppm}\end{array}$} & K & $\mathrm{Ca}$ & $\mathrm{Mg}$ \\
\hline & & \multicolumn{3}{|c|}{$\%$} & & \multicolumn{3}{|c|}{$\mathrm{cmol} / \mathrm{kg}$} \\
\hline $\begin{array}{c}2013 \\
a\end{array}$ & 5.5 & 0.33 & 0.57 & 0.05 & 0.37 & 0.97 & 5 & 0.14 \\
\hline $\begin{array}{c}2013 \\
\text { b }\end{array}$ & 5.7 & 1.41 & 2.44 & 0.14 & 0.81 & 0.59 & 10 & 2.1 \\
\hline 2014 & 5.4 & 0.59 & 1.02 & 0.06 & 3.01 & 0.18 & 6 & 0.69 \\
\hline
\end{tabular}

*a. Before initial cropping, b. End of first year cropping

\section{Meteorological Data}

The data on rainfall, temperature and relative humidity are presented (Table 2). The data on rainfall indicated that the month of September in the two years of study experienced the highest rainfall. This rainfall comes in torrent but sometimes for a short duration; the temperatures and relative humidity were high. The meteorological data for the two years (Table 2) clearly indicated that the 
highest monthly rainfall and maximum temperature was experienced during the cultivating seasons for the two years (August - October).

Table 2. Meteorological Data of the experimental site in 2013 and 2014

\begin{tabular}{|c|c|c|c|c|c|c|c|c|}
\hline Months & \multicolumn{2}{|c|}{ Rainfall (mm) } & \multicolumn{2}{|c|}{$\begin{array}{c}\text { Temperature } \\
{ }^{\circ} \mathrm{C}(2013)\end{array}$} & \multicolumn{2}{c|}{$\begin{array}{c}\text { Temperature } \\
{ }^{\circ} \mathrm{C}(2014)\end{array}$} & \multicolumn{2}{|c|}{$\begin{array}{c}\text { Relative } \\
\text { Humidity } \\
(\%)\end{array}$} \\
\hline & 2013 & 2014 & Min. & Max & Min. & Max & 2013 & 2014 \\
\hline January & 0.5 & 6.3 & 19.4 & 34.2 & 20.6 & 34.5 & 81 & 81 \\
\hline February & 39.2 & 34.2 & 22.7 & 34.8 & 20.7 & 35.3 & 81 & 82 \\
\hline March & 39. & 71.0 & 24.2 & 35.6 & 23.8 & 34.8 & 81 & 81 \\
\hline April & 181.8 & 321.4 & 23.6 & 32.3 & 22.5 & 32.7 & 81 & 81 \\
\hline May & 81.8 & 163.8 & 22.7 & 31.5 & 22.7 & 39.6 & 81 & 81 \\
\hline June & 132.9 & 154.4 & 20.9 & 34.2 & 21.9 & 30.4 & 80 & 81 \\
\hline July & 107.3 & 82.1 & 21.8 & 28.0 & 21.9 & 29.6 & 80 & 81 \\
\hline August & 17.7 & 94.9 & 21.4 & 27.8 & 21.3 & 27.5 & 80 & 80 \\
\hline September & 202.5 & 391.6 & 21.5 & 29.2 & 21.2 & 28.5 & 80 & 80 \\
\hline October & 154.3 & 259.4 & 21.7 & 31.0 & 21.7 & 31.6 & 80 & 81 \\
\hline November & 0.0 & 0.0 & 23.4 & 31.5 & 22.7 & 32.5 & 83 & 81 \\
\hline December & 11.4 & 0.0 & 19.4 & 33.5 & 19.4 & 33.2 & 82 & 82 \\
\hline Mean & 969.0 & 1579.4 & 21.9 & 32.0 & 21.7 & 32.5 & 81 & 81 \\
\hline
\end{tabular}

\section{Soil Porosity and Water holding capacity}

The data on porosity is presented in (Figure 1). The data showed that the mulched plots had significantly higher total porosity compared to control whereas plots under grass mulch had a higher total porosity relative to those under wood shavings. It was however observed, contrary to expectations that total porosity fell by at least $3 \%$ in the second year regardless of mulch applied. Similar trend was observed for the water holding capacity (Figure 2) of treated soil but at least $0.61 \%$ reduction in the second year of the experiment. Varying the amount of mineral fertilizer applied to the soil did not affect the total porosity and water holding capacity of the soil. There were no significant interaction effects between the treatments on total porosity and water holding capacity. 


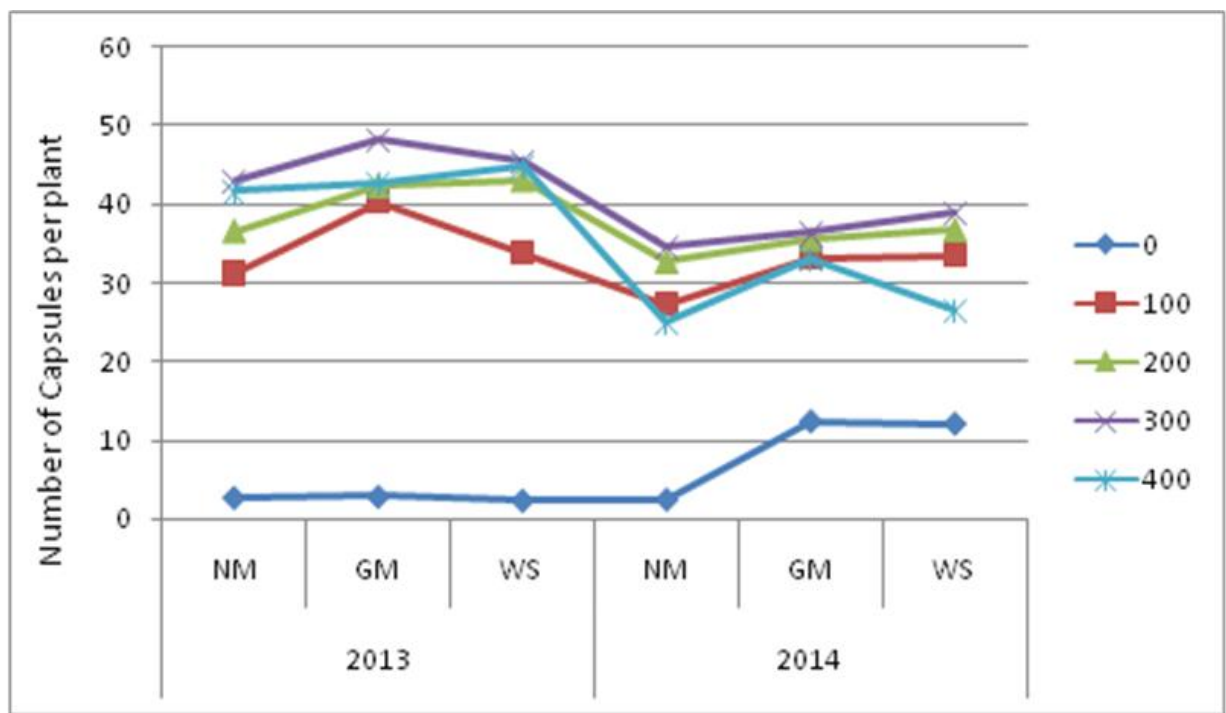

Fig 1. Effects of mulching and NPK fertilizer on the number of capsules per plant of sesame in 2013 and 2014

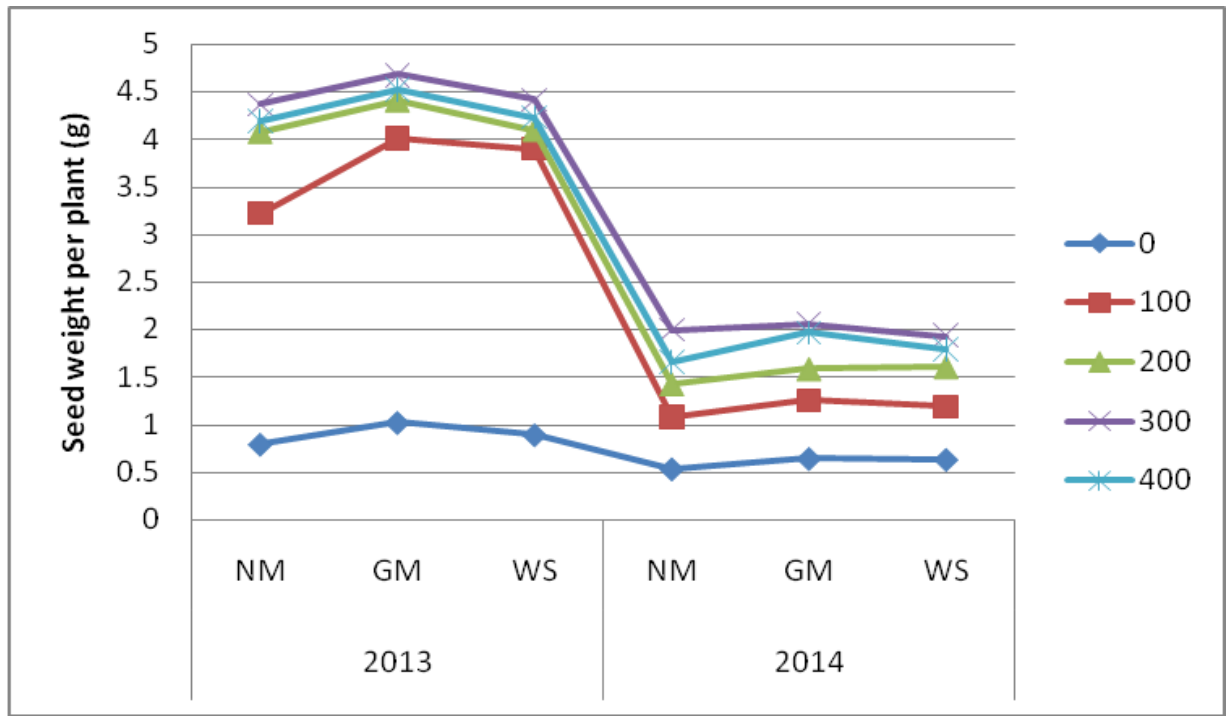

Fig 2. Effects of mulching and NPK fertilizer on the seed yield per plant (g) of sesame in 2013 and 2014

\section{Vegetative Traits of Sesame in 2013 and 2014}

Growth parameters of Sesame as influenced by mulching and Inorganic fertilizer rate in 2014.

The data on plant height of sesame at 4, 6 and 8 WAP are presented in Table 4. The data indicated that there was a trend in the performance of sesame across the three sampling periods. Increasing fertilizer rates resulted in an 
increase in the plant height of sesame up to the highest rate of 400 kgha-1 but no significant difference was observed except at $8 \mathrm{WAP}$ when significant difference $(\mathrm{P}<0.05)$ was observed between the treated plots and the control. Using grass mulch produced the tallest plants, although there was no significant difference between the three mulch types. In addition, there was no significant interaction between mulch types and fertilizer rates across the three sampling periods. In 2014, a similar trend of what happened in 2013 occurred but significant $(\mathrm{P}<0.05)$ differences across the three sampling periods using inorganic fertilizer was observed.

Table 4: Effects of mulching and NPK fertilizer on plant height $(\mathrm{cm})$ of sesame at 4, 6 and 8 WAP in 2013and 2014

\begin{tabular}{|c|c|c|c|c|c|c|c|c|c|c|c|c|c|}
\hline & & \multicolumn{4}{|c|}{4 weeks after planting } & \multicolumn{4}{|c|}{6 weeks after planting } & \multicolumn{4}{|c|}{8 weeks after planting } \\
\hline & $\begin{array}{c}\text { Fertilizer } \\
\text { Rate } \\
\text { kg/ha }\end{array}$ & $\begin{array}{c}\text { No } \\
\text { mulching }\end{array}$ & $\begin{array}{l}\text { Grass } \\
\text { Mulch }\end{array}$ & $\begin{array}{c}\text { Wood } \\
\text { shavings }\end{array}$ & Mean & $\begin{array}{c}\text { No } \\
\text { mulching }\end{array}$ & $\begin{array}{l}\text { Grass } \\
\text { mulch }\end{array}$ & $\begin{array}{c}\text { Wood } \\
\text { shavings }\end{array}$ & Mean & $\begin{array}{c}\text { No } \\
\text { mulching }\end{array}$ & $\begin{array}{c}\text { Grass } \\
\text { mulching }\end{array}$ & $\begin{array}{c}\text { Wood } \\
\text { shavings }\end{array}$ & Mean \\
\hline & 0 & 10.83 & 11.90 & 10.43 & 11.06 & 24.30 & 21.47 & 20.93 & 22.23 & 40.8 & 47.50 & 40.6 & 43.0 \\
\hline & 100 & 15.37 & 15.67 & 16.53 & 15.86 & 49.87 & 45.33 & 43.87 & 46.36 & 83.4 & 95.5 & 82.3 & 87.1 \\
\hline 2013 & 200 & 18.90 & 20.40 & 21.07 & 20.12 & 63.90 & 71.87 & 63.50 & 66.42 & 96.5 & 113.6 & 109.5 & 106.5 \\
\hline & 300 & 23.17 & 25.80 & 25.87 & 24.94 & 72.00 & 87.70 & 71.20 & 76.97 & 113.1 & 125.3 & 126.4 & 121.6 \\
\hline & 400 & 26.50 & 31.87 & 29.63 & 29.33 & 79.15 & 99.17 & 85.90 & 88.07 & 128.6 & 134.9 & 135.3 & 132.9 \\
\hline & Mean & 18.90 & 21.13 & 20.71 & & 57.84 & 65.11 & 57.08 & & 92.5 & 103.3 & 98.8 & \\
\hline & $\begin{array}{l}\text { LSD- } \\
0.05\end{array}$ & \multicolumn{2}{|c|}{$\begin{array}{c}\text { Mulching (M) } \\
\text { ns }\end{array}$} & & & ns & & & & ns & & & \\
\hline & & \multicolumn{2}{|c|}{ Fertilizer $(\mathrm{F}) \mathrm{ns}$} & & & $\mathrm{ns}$ & & & & 13.32 & & & \\
\hline & & \multicolumn{3}{|c|}{ Interaction $(\mathrm{M} \times \mathrm{F}) \mathrm{ns}$} & & ns & & & & ns & & & \\
\hline & 0 & 22.37 & 21.20 & 17.50 & 20.36 & 35.3 & 45.0 & 53.3 & 44.6 & 66.27 & 71.50 & 69.63 & 69.13 \\
\hline & 100 & 19.93 & 27.00 & 22.33 & 23.42 & 75.0 & 75.7 & 79.0 & 76.6 & 103.40 & 105.93 & 102.07 & 103.13 \\
\hline \multirow[t]{7}{*}{2014} & 200 & 23.90 & 31.87 & 27.00 & 27.59 & 88.7 & 84.0 & 96.3 & 89.7 & 134.07 & 139.10 & 131.27 & 134.31 \\
\hline & 300 & 36.83 & 35.33 & 29.70 & 23.96 & 100.0 & 104.3 & 107.3 & 103.9 & 142.30 & 144.93 & 149.90 & 145.71 \\
\hline & 400 & 30.07 & 37.47 & 32.47 & 33.37 & 128.7 & 137.0 & 123.7 & 129.8 & 145.13 & 145.53 & 151.20 & 147.79 \\
\hline & Mean & 26.62 & 30.57 & 26.00 & & 85.5 & 89.2 & 91.9 & & 117.83 & 121.40 & 120.81 & \\
\hline & $\begin{array}{l}\text { LSD- } \\
0.05\end{array}$ & \multicolumn{2}{|c|}{ Mulch (M) ns } & & & ns & & & & ns & & & \\
\hline & & \multicolumn{3}{|c|}{ Fertilizer (F) 5.713} & & 11.28 & & & & 5.016 & & & \\
\hline & & \multicolumn{3}{|c|}{ Interaction $(\mathrm{M} \times \mathrm{F}) \mathrm{ns}$} & & $\mathrm{ns}$ & & & & ns & & & \\
\hline
\end{tabular}

Number of leaves at 4, 6 and 8 are in Table 5. The data at 4 and 6WAP showed that, there was a trend as the level of fertilizer increased. The highest number of leaves was produced at the $400 \mathrm{kgha}-1$ treated plots which was at par with the 300 kgha-1 but significantly different $(\mathrm{P}<0.05)$ from the other treatments. The highest number of leaves was produced by the grass mulched 
plots which was significantly different $(\mathrm{P}<0.05)$ from the other mulch types. However, no significant mulch and fertilizer interaction was observed. At 8 WAP, the data showed that increasing fertilizer rates also resulted in an increase in the number of leaves. The highest number of leaves was attained at the 400 kgha-1rate of application, which was significantly different $(\mathrm{P}<0.05)$ from the control. Although the grass mulched treated plots produced the highest number of leaves, there was no significant difference between the mulch types. However, no significant mulching and fertilizer rate interaction effect was observed.

Table 5: Effects of mulching and NPK fertilizer on the number of leaves per plant of sesame at 4, 6 and $8 \mathrm{WAP}$ in 2013 and 2014

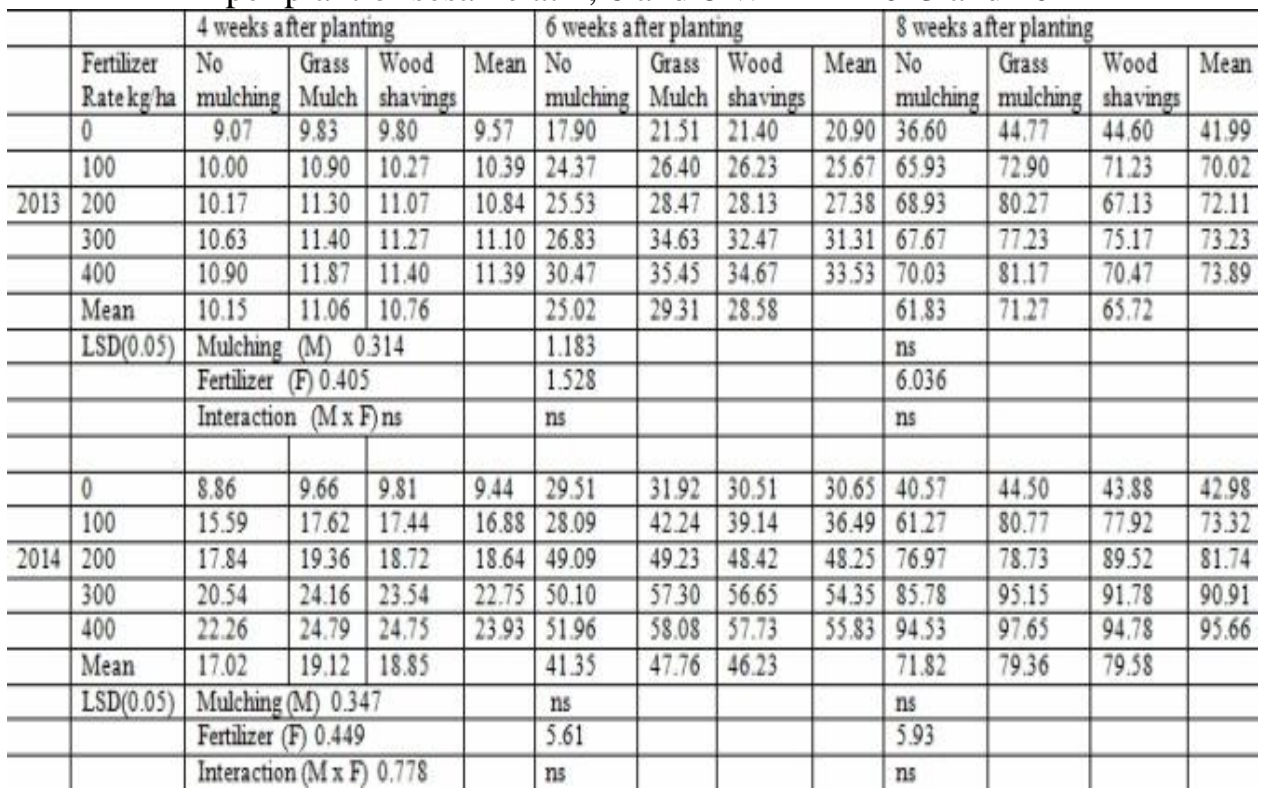

Data on the number of leaves in 2014 indicated that at 4 WAP, significant differences $(\mathrm{P}<0.05)$ were observed by using mulch, fertilizer and there was mulching and fertilizer interaction effects. At 6 and 8 WAP, using fertilizer increased the number of leaves up to the highest rate of application and significant differences $(\mathrm{P}<0.05)$ was observed between the treated plots and the control but no significant mulching effect. Nevertheless, no significant mulching and fertilizer interaction effect was observed.

The number of branches of sesame at 4.6 and $8 \mathrm{WAP}$ are in Table 6 . The data on the number of branches showed that using mulch produced the highest number of branches significantly $(\mathrm{P}<0.05)$ across the three sampling periods but no significant fertilizer, mulching and fertilizer interaction was observed. In 2014, the data on the number of branches showed that significant effects $(\mathrm{P}<0.05)$ were observed by using mulch and fertilizer but no significant mulching and fertilizer interaction across the three sampling periods. 
Table 6: Effects of mulching and NPK fertilizer on the number of branches per plant of sesame at 4, 6 and 8 WAP in 2013 and 2014

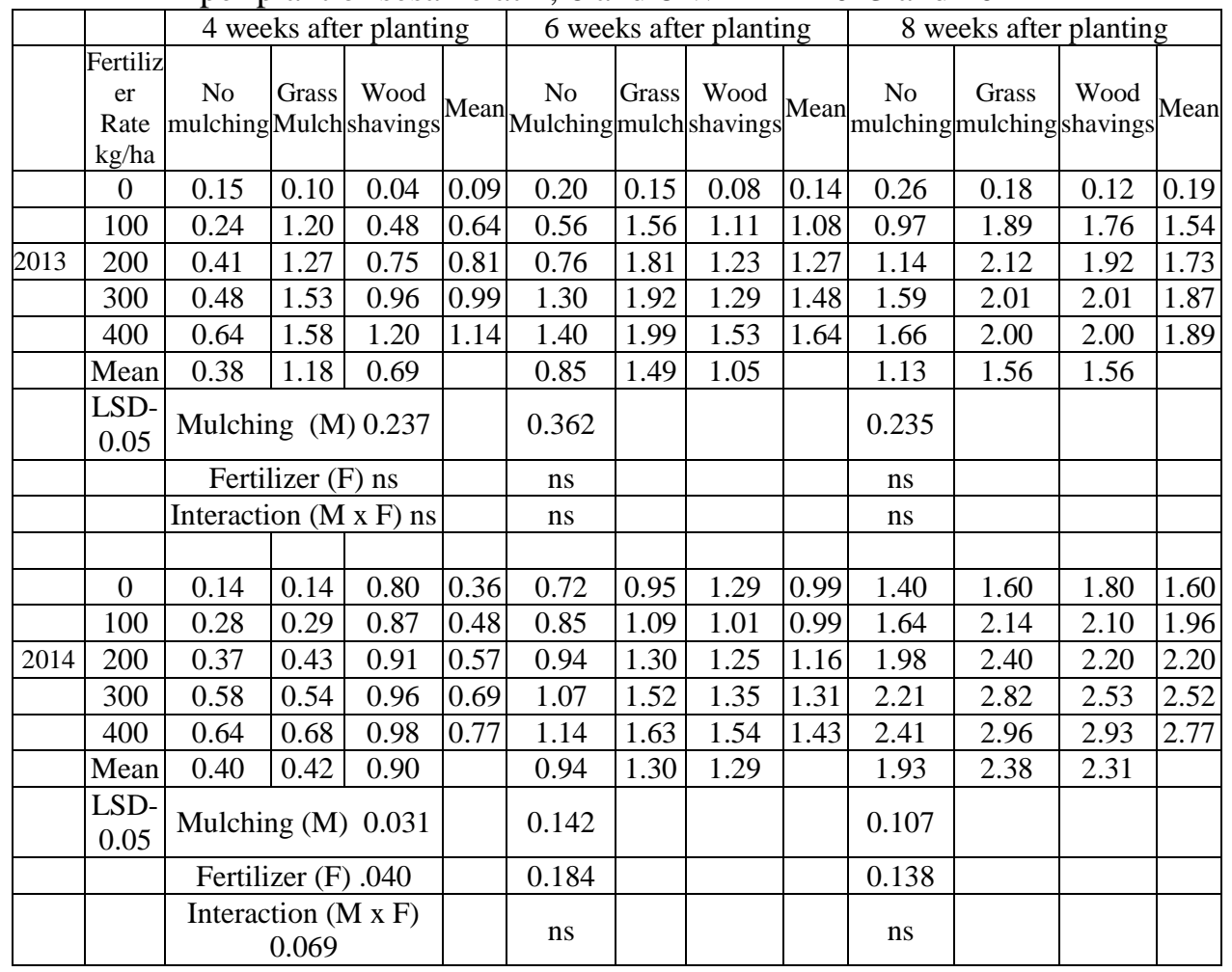

\section{Yield parameters of sesame in 2013 and 2014}

The data on the number of capsules per plant of sesame in 2013 and 2014 are presented in (Figure 1).The data indicated that the grass-mulched plots produced the highest number of capsules per plant but no significant difference was observed. There was a trend when different rates of fertilizer was used. Increasing the rate of fertilizer resulted in an increase in the number of capsules per plant up to $300 \mathrm{kgha}-1$ and declined at the $400 \mathrm{kgha}-1$ rate of application which was significantly different $(\mathrm{P}<0.05)$ from the other treatments. However, no significant mulching and fertilizer interaction was observed across the two years.

The seed weight per plant of sesame for the two years of study as affected by mulching and fertilizer rates presented in (Figure 2) showed that using grass mulch produced the highest seed weight per plant and outpaced other mulch types significantly $(\mathrm{P}<0.05)$; also there was a trend, as the level of fertilizer application increased up to 300 kgha- 1 rate of application and declined at the 400 kgha-1, there was an increase in the seed weight of sesame which was significantly different $(\mathrm{P}<0.05)$ from the control and there was mulch $\mathrm{x}$ fertilizer interaction effects $(\mathrm{P}<0.05)$ in the 2013 but no interaction effects in 2014. 
Data on the seed weight per hectare as influenced by mulching and NPK fertilizer application in 2013 and 2014 presented in (Figure 3). The data indicated that using grass mulch produced the highest seed weight per hectare which significantly $(\mathrm{P}<0.05)$ differed from other mulch types. Using NPK fertilizer at the rate of $300 \mathrm{kgha}-1$ produced the highest seed weight per hectare which was significantly different $(\mathrm{P}<0.05)$ from the control and there was mulch $\mathrm{x}$ fertilizer interaction effects $(\mathrm{P}<0.05)$ in the 2013. However, no significant mulch $\mathrm{x}$ fertilizer interaction effects was observed in 2014.

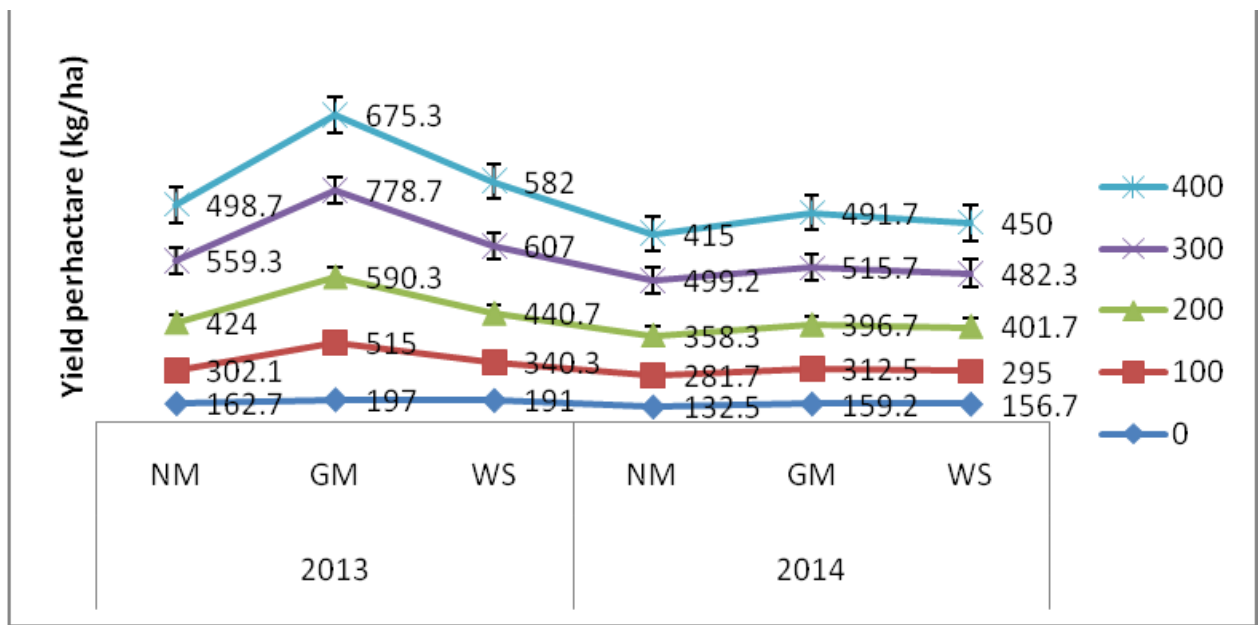

Fig. 3 Effects of mulching and NPK fertilizer on the yield per hectare $(\mathrm{kg})$ of sesame in 2013 and 2014

\section{Combined Yield of sesame (2013 and 2014)}

The result of the effect of mulching and fertilizer rates on the combined yield (2013 and 2013) of sesame presented in (Fig 4). The result showed that the grass mulched plots out-yielded the no mulch and wood shaving mulched plots significantly $(\mathrm{P}<0.05)$; using NPK fertilizer at $300 \mathrm{kgha}-1$ produced the highest yield per hectare which was significantly $(\mathrm{P}<0.05)$ different from the other treatments but no significant mulch and fertilizer interaction effects was observed.

The moderately low fertility status of the experimental site could be attributable to increased cropping intensity. Eifediyi et al. (2013) had earlier reported that soils of the study area are deficient in nutrients especially $\mathrm{N}, \mathrm{P}$ and K. Gbedegasin and Akinbolu (1995) reported that soils of the southern guinea savannah zone of Nigeria are low in organic carbon, total nitrogen and available phosphorus. The poor nutrient status of the soil could also be adduced to constant bush fire, which deprives the soil of much needed organic matter thereby making it bare and prone to the vagaries of weather, which often results in soil erosion. These poor soil conditions coupled with the comparatively higher rainfall and maximum temperature experienced during the cultivating season therefore affirms the need for mulching as a soil conservation approach on this soil for 
sustainable sesame production. Ansary and Roy (2005) had earlier posited that mulching brings about moisture conservation at the root zone and hence prevent leaching of fertilizer nutrients thereby promoting growth and yield parameters in tomatoes. The mulch was able to absorb some of the radiation energy thus functioning as insulators. The soil under a mulch cover therefore receives less heat during the day and less heat means less evaporation and hence increased soil moisture content (Muller - Samann and Kotschi, 1994).

The significantly higher porosity in unmulched plots may be attributable to improved organic matter content whereas differences between mulched types may be due to their $\mathrm{C} / \mathrm{N}$ ratio which will determine the extent of their microbial activity and hence the speed of decomposition and subsequent mineralization. Grass mulch is thought to have lower $\mathrm{C} / \mathrm{N}$ ratio compared to wood shavings and hence will therefore support relatively higher microbial activity which will invariably culminate in higher porosity, infiltration rate and water holding capacity (Martens and Frankenberger, 1992). The positive effect of organic mulches in increasing the available plant nutrient content in the soil is well documented (Saroa and Lal, 2004).

The increase in growth parameters of sesame in mulched plots can be adduced to sufficient soil moisture near the root zone of the crop that minimized evaporation loss due to mulching. Mulch is a source of organic matter to the soil and when it decomposes with subsequent mineralization releases nutrients that are useful to plants; hence increased growth attributes of sesame. Liasu and Achakzai (2007) had earlier reported that mulch and fertilizer when combined improved the growth attributes of tomatoes than when fertilizer or mulch is used alone. Malik et al. (2003), Olowe and Busari (2000) also had reported significant increase in plant growth attributes of sesame when NPK fertilizer was applied. The increase in growth attributes can be adduced to a combination of factors such as increased water holding capacity, increased porosity and reduction in the leaching of nutrients. Lal et al. (1980) and Manrique (1995) earlier posited that mulches enhance crop productivity by improving water conservation, soil physical and chemical properties.

From the results obtained, it is clear that yield and yield attributes of sesame were significantly increased by the application of fertilizer. Both yield and yield attributes of sesame were optimum at $300 \mathrm{kgha}^{-1}$ of fertilizer application because the fertilizer used during the experiment has higher nutrient content compared with mulch. The effects of mulching on the number of capsules per plant were significantly higher than the control. Similar responses had earlier been reported by Farios- Larios and Orozos- Santos (1997) who suggested that length of fruit of watermelon was greatly enhanced by the application of mulch compared to the control. The unmulched plots may have experienced increased evaporation from soil, increased leaching of nutrients and competition from weeds.

The significant effects produced by the $400 \mathrm{kgha}^{-1}$ over the $300 \mathrm{kgha}^{-1}$ in terms of growth parameters could not be translated into yield components as the 
yield of sesame was significantly increased by the application of $300 \mathrm{kgha}^{-1}$ of NPK. This may be due to antagonistic behavior of one nutrient over the other, which may have promoted vegetative growth at the expense of seed formation. Arancibia and Motsenbocker (2008), Farios-Larios and Orozco-Santos (1997) had reported that marketable yield from mulched treatments were higher than those produced on unmulched plots in watermelon. Aruna et al. (2007) also reported increase in tomato in mulched plots and Angrej-Ali and Gaur (2007) in strawberry and Ibarra et al. (2001) in muskmelon.

In addition, the increase in yield of sesame could be attributed to soil conservation (Bhella, 1988) and reduced weed infestation in plots that were treated with mulches. Weed infestations were reduced in plots irrespective of the mulch type. Mulches, particularly grass mulch gave higher yields and affected other yield factors when compared to the wood shavings and non- mulch applications. This can be attributed to the fact that mulches reduce leaching, modify soil nutrient status and hence increase fertilizer use efficiency (Mbagwu, 1990). The significant interactions between mulching and NPK fertilizer application on the seed yield of sesame is an affirmation of the fact that combined applications of both mulch which is a form of organic manure and inorganic manure are essential for increased yield. This finding is in conformity with the findings of Olowe and Busari (2000) who asserted that inorganic and organic fertilizer increased the growth and yield of sesame.

The average yield of the two years of study indicated an overall seventy-one percent increase in seed weight per hectare in the grass-mulched plot over the control. Several workers had earlier reported yield increases by applying mulch. Abak et al. (1991) observed an increase in total yield (62\%) and yield of early melon covered by mulch while Lal (1978) reported an increase of 38, 10 and 22 consecutive years for maize under mulch.

The differences in yield in the two years of study could be attributed to weather variability bearing in mind that the same variety and cultural practices were carried out during the period. Semenov and Porter (1995) had earlier reported that rainfall and temperature are major determinants of crop growth and yields especially in rain fed agriculture; rainfall and temperature from season to season greatly affects water availability to crops and thus pose crop production risks.

\section{CONCLUSIONS}

The higher yields of sesame were obtained in the mulched plots because of better water holding capacity and nutrient conservation compared to the unmulched plots. Mulch types had effect on the cultivation of sesame. The best agronomic and yield traits was observed from the plots mulched with grass. Grasses are suitable as mulch materials in the savanna zone as they are available all the time and its use should be encouraged and recommended for effective production of sesame for optimum yield especially when rainfall is erratic or too much. 


\section{REFERENCES}

Abak, K., Y. Pakyürek, N. Sarı and S. Büyükalaca (1991). Sera Kavun Yetiştiriciliğinde Malç ve Farklı Budama Yöntemlerinin Verim, Erkencilik ve Meyve İriliği Üzerine Etkleri.Çukurova Üniversitesi Ziraat Fakültesi Dergisi 6(4): 39-50.

Abubakar, S. S., J. E. Onyibe, and E. B. Tologbonshein (1998). The role of extension, research and information dissemination in enhancing beniseed production and marketing for resource poor farmers. Proceedings of the First Workshop on Beniseed held at the National Cereal Research Institute, Badegi, Nigeria, March 3rd -5th, 1998. Pp86-89.

Aguyoh J., Taber H.G and Lawson V. (1999). Maturity of fresh market sweet corn with direct seeded plants, transplants, clear plastic mulch and row cover combinations. Hort Technology 9 (3): 420-425.

Alegbejo, M.D. (2003). Sesame: A Potential Industrial and Export Oilseed Crop in Nigeria Journal of Sustainable Agriculture. 23(1):59-76.

Ahamefule, H. E., Obi, E. M., Amana, S.M., Peter, P.C., Eifediyi, E. K. and Nwokocha, C. C. (2014). Response of cowpea (Vigna unguiculata L. Walp) to changes in hydraulic properties of a spent crank-case oil contaminanted Ultisols under biostimulation Nigerian Journal of Food and Environment 10: 99- 105

Ahamefule, H. E. and Peter, P.C (2014). Cowpea ( Vigna unguiculata L. Walp) response to phosphorus fertilizer under two tillage and mulch treatments. Soil Tillage Research 136: 70 - 75 .

Angrej Ali and Gaur, G. S. (2007). Effect of mulching on growth, fruit yield and quality of strawberry (Fragaria x ananassa Duch.). Asian J. Hort. 2(1): 149-151.

Anikwe M.A.N., Mbah C.N., Ezeaku P.I., Onyia V.N. (2007). Tillage and plas-tic mulch effects on soil properties, and growth and yield of cocoyam (Colocasia esculenta) on an ultisol in south-eastern Nigeria. Soil and Tillage Research 93: 264-272.

Ansary, S.H. and Roy, D. C. (2005). Effect of irrigation and mulching on growth, yield and quality of watermelon (Citrullus lanatus Thunb.). Environment and Ecology, 23(Spl-1): 141-143.

Arancibia, R.A. and C.E. Motsenbocker (2008). Differential watermelon fruit size distribution in response to plastic mulch and spun bonded polyester row cover. Hort Technology 18:45-52.

Aruna, P.; Sudagar, I.P.; Manivannan, M. I.; Rajangam, J and Natarajan, S. (2007). Effect of fertigation and mulching for yield and quality in tomato cv. PKM-1. Asian J. Hort., 2(2): 50-54.

Bennett, M.R. and Wood, I.M. (1995) Proceedings of First Australian Sesame Workshop, Northern Territory Dept. of Primary Industry and Fisheries, Darwin.

Bhella, H. S. (1988). Effect of trickle irrigation and black mulch on growth, yield and mineral composition of watermelon. Hort. Sci., 23(1):123-125.

Bremner, J. M. (1965). Total N: In: C. A. Black (ed) Methods of soil analysis part 2, Agron. No 9. American Society of Agronomy Madison, Wisconsin.1149-1178.

Cadavid, L. F.; EL - Sharkawy, M.A. and Aosta, A. (1998). Long - term effects of mulch, fertilization and tillage on cassava grown in sandy soils in northern Columbia. Field Crops Research 57, 45.

Eifediyi, E. K., Mohammed, K. O. and Remison, S. U. (2013). Influence of organomineral fertilizer (OMF) on the performance of jute mallow (Corchorous olitorius) in North Central Nigeria Nigerian Journal of Agriculture, Food and Environment. 9(3):54-58 . 
Farias-Larios, J. and Orozco-Santos, M. (1997). Effect of Polyethylene Mulch Colour on Aphid Populations, Soil Temperature, Fruit Quality and Yield of Watermelon Under Tropical Conditions. New Zealand Journal of Crop and Horticultural Science 25: 369-374. Doi/pdf/10.1080/01140671.1997.9514028.

Gbadegesin; A and Akinbolu, G. E. (1995).Nigeria Reference Soil of the Southern Guinea Savannah of South Western Nigeria: Soil Brief Nigeria 7. University of Ibadan and International Soil Reference Information Center Wageningen pp13.

Haruna, I. M. and Usman, A. (2005). Agronomic practices that enhances increased yield and seed quality of sesame (Sesamum indicum L.). A paper presented at the: Agric. Transformation Day (sesame and rice) organized by OLAM Nig. Ltd. Held at Agro Millers Ltd. Compound, Uni- Agric. Road, Makurdi, 4th Feb., 2005.

Ibarra Jimenez, L.; Zermeno Gonzalez, A.; Munguia Lopez J., Quezada Martin, M. A. R. and Rosa Ibarra, M. de La. (2008). Photosynthesis, soil temperature and yield of cucumber as affected by colored plastic mulch. Acta Agriculturae 58(4): 372- 378.

Khurshid K., Iqbal, M., Arif, M. S., Nawaz,A. (2006 ). Effect of tillage and mulch on soil physical properties and growth of maize. International Journal of Agric. Biology 5: $593-600$.

Kuo, S. (1996). Phosphorus. In methods of soil analysis. Part 3 Chemical methods. D. L. Sparks (Ed.) American Society of Agronomy, Madison pp 869 - 919.

Lal, R., De Vleeschauver, D., Malafa, R. N. (1980). Changes in properties of a newly cleared tropical alfisols as affected by mulching. Soil Science Society of American Journal 44:827 833.

Lal, R. (1974). Soil temperature, soil moisture and maize yield from mulched and unmulched tropical soils. Plant and Soil 40(1), 129-143.

Lal, R. (1978). Influence of within and between row mulching on soil temperature, soil moisture, root development and yield of maize (Zea mays L. ) in a tropical soil. Field Crops Research 1(2): 127 - 139

Liasu, M.O. and Achakzai, A.K.K (2007).Influence of Tithonia diversifolia leaf mulch and fertilizer on the growth and yield of potted tomato plant American Eurasian Journal of Agriculture and Environmental Science 2: 335 -340

Malik, A.M. M.F. Salem, M.A. Cheema, and Ahmed. S. (2003). Influence of Nitrogen Levels on Productivity of Sesame (Sesamum indicum L) under Varying Planting Pattern International Journal of Agriculture and Biology 4:490-492.

Manrique, L. A. (1995). Mulching in potato systems. Journal of Plant Nutrition 18: 593 616.

Martens, D. A .and Frankenberger, W. T. (1992). Modification of infiltration rates in an organic- amended irrigated soil. Agronomy Journal 84, 707- 717.

Mbagwu, J.S.C (1990). Land development in the tropics. Ecophysical perturbation and a proposed methodology for suitability assessment. Beitr. Trop. Landirtse Vet. Med. 28: $29-41$

Muller-Samann, K. M. and Kotshi, J. (1994). Sustaining growth: Soil fertility management in tropical smallholdings. CTA/ GTZ Margraf Verlag, Germany 486pp.

Nelson, D. W. and Sommers, L. E. (1996). Total carbon, organic C and organic matter. In D. L. Sparks ( Ed.) Methods of Soil Analysis.Part 3 Chemical method, SSSA Book series Number 5, Madison, W.I. Am. Soc. Agron.

Olowe, V. I. O. and Busari, L. D. (2000). Response of Sesame (Sesamum indicum L.) to Nitrogen and Phosphorous Application in Southern Guinea Savanna of Nigeria. Tropical Oilseed J. Pp $30-37$. 
Rao, V. P., Raikhelkar, S. V. and Sondge, V. D. (1994). Effect of irrigation and fertilization on yield and its components in sesame (Sesamum indicum L.). Indian Journal of Agricultural Science 64: 93-100.

Saroa, G. S. and Lal, R. (2004). Mulching effects on phosphorus and sulfur concentrations in a Miamian soil in Central Ohio, USA. Land Degrad. Develop. 15: $351-365$.

Schilling, R. and Cattan, P. (1991). Sesame cultivation in tropical Africa. Oleagineux 46: 129-131.

Semenov, M. A. and Porter, J.R. (1995). Climatic variability and the modeling of crop yields. Agr. Forest Meteorol.73:265 - 283 doi: 10.1016/0168-1923(94) 05078-K

Singh, R., S., Sharma, R.R. and Goyal, R.K. (2007). Interacting effects of planting time and mulching on "Chandeler" strawberry (Fragaria x ananassa Duch.). Sci. Hortic. $111,344-351$.

Tian, G., Kang B. and Brussoard L. (1994). Mulching effects with plant residues with chemically contrasting composition of maize growth and nutrient accumulation IITA Res. 9: 7 - 11

Tunde - Akintunde, T. Y. and Akintunde, B.O. (2007).Effect of moisture content and variety of selected properties of benniseed Agric Eng Internl: The CIGR Ejournal Manuscript FPO 7021. Vol IX.

Vossen, H. A. M and Mkamilo, G. S. (2007). Plant Resources of Tropical Africa. Vegetable oils. PROTA Foundation, Wageningen, Netherlands Publishers, Leiden, Netherlands/CTA, Wageningen, Netherlands 237 pp.

Wien, H.C., Minotti, P. L. and Grubinger, V. P. (1993). Polyethylene mulch stimulates early root growth and nutrient uptake of transplanted tomatoes. Journal of the American Society for Horticultural Science 118:207 - 211. 